The influence of land use type and municipal context on urban tree species diversity

Kirstin S. Bourne

*Tenley M. Conway

Department of Geography

University of Toronto

3359 Mississauga Rd N

Mississauga, ON L5L 1 C6

Canada

*Corresponding author: tenley.conway@utoronto.ca, (t )905-828-3928, (f) 905-8285273

Key Words: urban forests; tree diversity; urban land use; alpha and beta diversity 
Post-Print Version of Bourne and Conway, 2014; DOI 10.1007/s11252-013-0317-0

\title{
The influence of land use type and municipal context on urban tree species diversity
}

\begin{abstract}
Recent research has focused on the ways urban forest patterns vary in relation to level of urbanization and socioeconomic characteristics, with most studies limited to one urban land type use or multiple non-differentiate land uses. Additionally, the majority of studies examining urban forest patterns focus on canopy cover extent, with less attention given to patterns of species diversity. This study explores how tree species diversity varies across different urban land uses and municipal boundaries to better understand the role of land use types in shaping urban forest patterns. The goal is addressed through an exploration of plot-level tree data in the urban municipalities of Peel Region located in the Greater Toronto Area (Ontario, Canada). Species composition and standard diversity metrics are calculated for eight land use types and four municipalities. Our results show that differences in diversity metrics and species composition are greater between urban land uses than municipalities. Moreover, Peel's urban forest has relatively high alpha diversity but many species are present on only one land use type. The results suggest that different causal processes are associated with each land use type, and that urban forest managers should adopt land use-specific strategies to meet species composition goals within the urban forest.
\end{abstract}




\section{Introduction}

Urban forests provide a well-documented set of environmental, social, economic, and health benefits (Tyrväinen et al. 2005). Along with an increasing understanding of the benefits associated with urban trees, there is a growing body of research examining spatial patterns of forests within cities (e.g. Heynen and Lindsay 2003; Iverson and Cook 2000; Landry and Chakraborty 2009; Talarchek 1990). This work has emphasized variations in urban forest conditions in relation to urbanization-level and among different socioeconomic groups. To date, the relationship between different land use types (i.e. residential commercial, etc.) and urban forest patterns has largely been overlooked. Yet the varied purposes, actors, and built surface requirements of each land use are likely associated with different urban forest conditions.

In addition to a lack of attention given to variations across land uses, relatively little research has examined patterns of tree species diversity within cities. The benefits of managing for a diverse forest are increasingly recognized within urban forestry. In general, higher levels of biodiversity allow for more complex ecosystem functioning and greater overall productivity, while creating more niche opportunities that positively feedback to further increase biodiversity (Groombridge and Jenkins 2002). Species diversity also provides greater security against environmental changes and stochastic events, including pest invasions, by increasing the potential for adaptation and survival (Alvey 2006). Urban biodiversity, in particular, increases the amount of exposure that city residents have to a wide spectrum of nature, which is an important element in stimulating people's desire to support conservation (Goddard et al. 2010). Additionally, evidence suggests a range of positive psychological and physiological effects are present when people interact with areas high in biodiversity (Cilliers 2010; Millard 2010). 
Urban biodiversity can play this role for city dwellers, and is especially important for those unable to travel to natural amenity-rich destinations outside urban landscapes.

The goal of this study is to begin to address the gap our understanding of urban tree species patterns through an exploration of tree species composition and diversity across several urban land use types and between neighboring municipalities. The study area is Peel Region (Ontario, Canada), located within in the Greater Toronto Area. Peel contains a mix of land uses distributed across its urban towns and cities, the level of government where most urban forestry policy exits. Plot-level tree data were used to calculate several common measures of species diversity. Specifically, species richness, evenness, and alpha and beta diversity were quantified for eight urban land use types and the four urban municipalities within the region. The following sections describe recent efforts to understand urban forests patterns, with emphasis on species diversity; present our methods and results; and discuss the implications of the results in the context of future research and urban forest management.

\section{Patterns of urban forest abundance and diversity}

Recent research focusing on patterns of tree abundance and diversity within urban landscapes has primarily taken two broad approaches: documenting patterns (1) along urbanization gradients and (2) across different socioeconomic groups. First, many studies have used an urban-rural gradient approach, proposed by McDonnell and Pickett (1990), as a way to explore ecological conditions in urban regions. This approach builds on the gradient analysis tradition within ecology, and is based on the idea that urban intensity provides a proxy for many of the dominant factors influencing ecological conditions in urban landscapes. In particular, 
Post-Print Version of Bourne and Conway, 2014; DOI 10.1007/s11252-013-0317-0

urban-rural gradients represent a unique situation where 'experimental' conditions with varying levels of urbanization exist that researchers are otherwise unable to create (McDonnell and Pickett 1990). While the gradient has been defined in a variety of ways, it is typically represented by a transect running from an urban center out to rural hinterlands or a simple density measure, like population density (Conway and Hackworth 2007). Critiques of this approach often focus on these simplistic representations of urban areas (Ramalho and Hobbs 2012).

In a 2008 review, McDonnell and Hahs identified 189 papers that adopted an urban-rural gradient approach to study the distribution of organisms, with studies of birds most common and studies of plants (often including but not limited to trees) representing about a quarter of papers reviewed. Across all taxa, McDonnell and Hahs (2008) identified six responses associated with the level of richness or abundance and the degree of urbanization, including both positive and negative relationships to urbanization, as well as more complex uni- and bi-modal relationships.

When focusing on tree species, McDonnell and Hahs (2008) found a positive relationship with an urbanization gradient index, which included factors like dominant land cover and population density. These results follow the general pattern of relatively high diversity levels in urban forests as compared to the surrounding region (Cornelis and Hermy 2004; Jim and Liu 2001). However, Ortega-Álvarez et al. (2011) and Berland (2011) documented highest tree species richness and canopy extent, respectively, at intermediate levels of urban development, while Burton et al. (2005) found that the diversity of woody plants increased as urbanization decreased. Other have concluded that plant richness-urbanization patterns, including trees, varied by transect or did not show a distinct pattern (Dallimer et al 2012; Porter et al. 2001). These results suggest that the relationship between urbanization and tree species richness is not 
Post-Print Version of Bourne and Conway, 2014; DOI 10.1007/s11252-013-0317-0

stable across landscapes, and additional factors, beyond degree of urbanization, are likely influencing the level of richness.

Drawing on political ecology theory, the second approach emphasizes the role of neighborhood socioeconomic conditions in determining urban forest patterns. In particular, recent research has explored whether the inequality hypothesis, which has been documented for a variety of environmental amenities and hazards within the environmental justice literature (c.g. Grineski et al. 2007), applies to the urban forest. There is a growing body of evidence suggesting that in many North American cities household income and other measures of neighborhood wealth are positively related to the extent of canopy cover (Emmanuel 1997; Heynen and Lindsay 2003; Iverson and Cook 2000; Landry and Chakraborty 2009; Pedlowski et al. 2002; Talarchek 1990). Additional socioeconomic factors often found to be correlated with tree cover include average level of education (Heynen and Lindsay 2003; Landry and Chakraborty 2009; Talarchek 1990), ethnic and racial composition (Flocks et al. 2011; Heynen et al. 2006; Landry and Chakraborty 2009; Troy et al. 2007), and percent of renters (Heynen et al. 2006). While presence of inequality is debated (Pham et al. 2012), at a minimum, an uneven distribution based on socioeconomic conditions does commonly exist. While this approach has primarily been used to explore the extent of canopy cover, similar relationships have been found in broader plant diversity studies (Acar et al. 2007; Cohen et al. 2012; Hope et al. 2003, 2006; Lubbe et al. 2010).

Although the urbanization gradient and neighborhood socioeconomic approaches have increasingly been adopted to explore patterns of trees species, surprisingly few studies have incorporated the potential effects of land use type. For example, many tree diversity studies focus exclusively on one specific urban land use type (Alison et al. 2008; Hobbs 1988; Tanner 
Post-Print Version of Bourne and Conway, 2014; DOI 10.1007/s11252-013-0317-0

and Gange 2005; Thompson et al. 2003; Trammell and Carreiro 2011; Weifeng et al. 2006;

Zipperer et al. 1991; Zipperer and Zipperer 1992) or are limited to only street trees and those on public land (Jim and Lui 2001; Nagendra and Gopal 2010; Sjöman et al. 2011). Alternatively, several studies examining urban vegetation patterns lump all urban land use together (Conway and Hackworth 2007; Emmanuel 1997; Heynen and Lindsay 2003; Muthulingam and Thangavel 2012). The importance of bridging these two extremes was illustrated by Godefroid and Koedam (2006) who found differences in plant species richness across six urban land uses in Brussels.

The different purposes of urban land use types means there is variation in available planting sites, general landscaping goals, and the types of people making decisions (i.e. residents, commercial property managers, municipal parks departments). These distinctions potentially contribute to different tree species compositions across land uses. Knowledge of similarities and differences between urban land use types is needed to better understand the mechanisms driving species diversity, and can provide guidance for future studies. For example, if two or more land uses have very different species composition and/or richness-levels, then the differences in conditions associated with those land uses, including the actors specific to each, need to be further examined to understand the causal processes. Documentation of species composition characteristics within and between land use types is also needed to develop successful management plans (Godefroid and Koedam 2006). Much of the urban forest is located on private property, requiring cooperation with land owners in order to maintain and grow a healthy forest. Understanding if and how the urban forest differs by land use type would help identify strategies targeting each group of land owners to ensure all parts of the urban forest are contributing to species composition goals. 


\section{Methods}

Study Area and Data

Peel Region occupies 1,254 $\mathrm{km}^{2}$ of southeastern Ontario (Canada), falling within the bounds of $43^{\circ} 35^{\prime} \mathrm{N}$ to $43^{\circ} 52^{\prime} \mathrm{N}$ and $79^{\circ} 37^{\prime} \mathrm{W}$ to $80^{\circ} 0^{\prime} \mathrm{W}$ (Figure 1). To the East is Toronto, Canada's largest city, while its southern boundary is Lake Ontario. The region of Peel is situated within the Great Lakes-St. Lawrence Forest Region, which is characterized by species such as Pinus strobus, Pinus resinosa, Tsuga canadensis, and Betula alleghaniensis (Hosie 1979). Carolinian forest species are also present (Waldron 2002).

Due to its proximity to Toronto, Peel has experienced rapid population growth within the last 40 years, with the southern part of the region nearly built-out. In 2006, 97\% of Peel's 1.16 million residences lived within one of the four urban municipalities located in the region: Bolton, Brampton, Caledon and Mississauga (Table 1). Brampton and Mississauga contain a mix of residential neighborhoods (ranging from large apartment towers to fully detached family homes), a number of shopping complexes and historic town centers. The other two municipalities, Bolton and Caledon, are much smaller is area and population; both are officially referred to as 'rural service centers'. In addition to variations in population density and median income, a major difference between the four municipalities is the percent of residents who are immigrants to Canada. In terms of urban forestry policy, all municipalities require developers to plant street trees on new residential development, often from a list of preferred trees, and have goals to replace any tree removed on public property. Mississauga limits property-owners to removing no more than five trees a year from their property without a permit, while the other municipalities do not regulate tree removal on private property. 
Stem counts and species type for 279 plots were used in the analysis (Figure 2). The data were collected in the summer of 2006 by the Toronto and Region Conservation Authority, initially for use in the UFORE Model (now i-Tree Eco; USDA 2011). Plot sites were selected throughout the study area using a spatially stratified random sampling method, with approximately 1 plot per 140 ha. Each plot is $11.3 \mathrm{~m}$ in diameter (a total circular area of $400 \mathrm{~m}^{2}$ ). Within a plot, every tree stem greater than $2.5 \mathrm{dbh}$ was counted and identified by species type. A plot's land use was determined using the Municipal Property Assessment Corporation's (MPAC) existing classification scheme. The MPAC is a non-governmental entity that conducts value assessments of all property in Ontario. The classification is at the property-level, with parking lots and all land covers assigned to a single land use within a property. Use of this classification allowed consistent land use definitions between the four municipalities (TRCA 2011). Plots initially classified as 'other', which includes vacant residential land, sports complexes, and constructions sites, were excluded from this analysis, resulting in eight land use classes (Table 2).

\section{Data Analysis}

First, simple species richness and total stem abundance was calculated for each of the eight land use categories and four municipalities. An analysis of variance (ANOVA) was used to investigate variations in plot-level species richness and stem abundance across both urban land use types and municipalities, while accumulation curves were created to test for exhaustive sampling. Second, more sophisticated diversity metrics (alpha diversity, species evenness, and beta diversity) were examined to better understand the distribution of tree species. Each of these 
Post-Print Version of Bourne and Conway, 2014; DOI 10.1007/s11252-013-0317-0

measures was calculated using the software Species Diversity and Richness III (Seaby and Henderson 2006).

Alpha diversity is a heterogeneity measure that combines the influence of richness and evenness to produce a single, community-specific diversity value. It is commonly described as providing a measure of 'within community diversity' (Southwood and Henderson 2000). Two metrics of alpha diversity were used in this study: Shannon-Weiner Index and the Simpson's Index.

The Shannon-Weiner Index, H', is a very common measure of alpha diversity (Margurran 1988; Southwood and Henderson 2000), which allowed us to compare diversity levels found in this study with previous work. It is a non-parametric index based on the proportional abundance of species taking into account both species richness and evenness, using the equation:

$$
\mathrm{H}^{\prime}=-\Sigma p_{i} \ln p_{i}
$$

Where $p_{i}$ represents the proportion of the population that belong to the $i$ th species. Typical values for $\mathrm{H}^{\prime}$ range from 1.5 to 3.5 when measurements are obtained from empirical data (Margurran 1988). While the index's prevalence provides a useful comparison against other urban forest studies, it has been criticized for being heavily biased by species number (Southwood and Henderson 2000) and moderately sensitive to sample size. To account for these biases, Simpson's Index, D, was also calculated. D is a dominance measure reflecting the probability that any two individuals drawn at random from an infinitely large community belong to the same species (Magurran 1988). It is much more sensitive to the most abundant species in a sample than it is to species richness. $\mathrm{D}$ is calculated using the following formula:

$$
\mathrm{D}=\Sigma \mathrm{p}_{\mathrm{i}}^{2}
$$


Post-Print Version of Bourne and Conway, 2014; DOI 10.1007/s11252-013-0317-0

The relationship between the diversity of a population and the value of $D$ is inverse. As diversity increases, D decreases from 1 to 0, somewhat counter intuitively (Waite 2000). Because of this, the measure is often employed in the more practical forms of 1-D or 1/D. Here, the reciprocal form was used, denoted as C. The lower bound for $\mathrm{C}$ is 1 (minimum diversity) and the maximum value for each sample is the number of observed species (maximum diversity). Together, H' and C illustrate the distribution of species abundance within a community and contribute to a comprehensive analysis.

Evenness was also calculated for each land use type and municipality to explore if each sample was dominated by a just a few species, as uneven species representation is a key concern of urban foresters (Kenney et al. 2011). Evenness was examined first by producing rankabundance curves, allowing for assumptions to be made about the ecology of each community, and then using Simpson’s measure of evenness to obtain a quantifiable measure of the distribution of diversity within a community. The latter measure is obtained by manipulating the Simpson’s Index of diversity, $\mathrm{D}$, into a complimentary evenness measure, $\mathrm{E}_{1 / \mathrm{D}}$, using the following formula:

$$
\mathrm{E}_{1 / \mathrm{D}}=(1 / \mathrm{D}) / \mathrm{S}
$$

Where $\mathrm{S}$ is the number of species in the sample. The resultant evenness measure ranges from 0 (no species equitability) to 1 (total species equitability).

Beta diversity is the measure of the difference in diversity that exists between communities. It was used in this study to quantify the amount of species diversity that exists between each of the distinct land use types and between municipalities. The original measure of beta diversity, $\beta_{W}$, was developed by Whittaker (1960). However, because this metric requires a 
standard sample size, $\beta_{W}$ is not a valid measure to use with this dataset. In order to overcome this sample size dependency, an adaptation on $\beta_{W}$ was introduced by Harrison et al. (1992).

Harrison's measure, $\beta_{\mathrm{H} 1}$, is calculated as:

$$
\beta_{\mathrm{H} 1}=\{[(\mathrm{S} / \alpha)-1] /(\mathrm{N}-1)\} * 100
$$

Where $S$ represents the total number of species in the system, $\alpha$ represents the average sample diversity assuming that all samples are a standard size and diversity is species richness and $\mathrm{N}$ is the number of plots in a sample population (Magurran 2004). Beta diversity was calculated between each land use pair, resulting in 32 pair-wise comparisons. The average value associated with each land use type was then determined. The process was repeated to calculate average beta diversity for each municipality.

\section{Results}

In total, the 2006 survey included 4,122 stems within the 279 plots in Peel. This sample population was comprised of 179 different species. On average, each plot had 15 stems and five species. The three most abundant species (and their percentage of the total population) are: Thuja occidentalis (15\%), Rhamnus cathartica (11\%), and Fraxinus americana (8\%). Thus, three species account for $34 \%$ of the sample, while the ten most common species equals $58 \%$. 


\section{Urban Land Use Types}

The average number of stems per plot for each land use type ranges from 3 to 29, while the range in average number of species per plot is much narrower (Table 3). The results of the ANOVA confirmed that plot-level stem abundance $(\mathrm{F}=3.85, \mathrm{p}<0.01)$ and species richness $(\mathrm{F}=$ -11.08, $\mathrm{p}<0.01$ ) varies significantly across land use type. The varied distribution between land uses justifies a more in-depth analysis of these relationships. The species accumulation curves suggest that four land uses (residential, vacant land, commercial and parkland) were sampled nearly exhaustively (Figure 3). Not surprisingly, these are the most common land uses with the highest number of plots.

The majority of the results of the Shannon-Weiner Index (H') fall within the normal range (1.5-3.5) reported in the literature for all ecosystems (Table 4; Magurran 1988). Only residential land exceeds this range, indicating that it has the highest degree of within community diversity, and significantly so. The rankings of alpha diversity values were the same for both Simpson's Index and H’. However, substantial differences exist between the rank order of alpha diversity values and the simple species counts, reinforcing the importance of employing the more robust analysis technique.

Rank abundance curves, illustrating the degree of evenness of species distributions across each land use class, all fell within a range between the log and log normal distribution models. Both models represent species distributions that are uneven, having few abundant and many rare species. Similarly, the Simpson’s E values for all the land use types in Peel Region were relatively very low (Table 4), which supports the findings that a small number of species dominate the composition in each land use type. 
In addition to the abundance of just a few dominate species, land use type-specific species are much more common in Peel than generalist species, making the distribution of land use an important factor in the distribution of tree species. Of the 179 total species that occur in the Peel Region sample, 48\% were found in plots of only one land use type. Of those, $69 \%$ were found on residential land. Only three species were identified on plots of all eight land use types (Acer negundo, Acer saccharum, and Rhamnus cathartica). Two of these three generalist species are native to the landscape; Rhamnus cathartica is not. Average pair-wise beta diversity values range from 52 to 69 (Table 4), with $\beta_{\mathrm{H} 1}$ values for specific pairs of land use classes ranging from 34 to 87 . These values support the assessment that different compositions of trees species exist on different land uses.

Tree composition on the four most common land use types, which also have the most robust samples, are described in more detail below. First, residential land, the most common urban land use type in Peel, represents 52\% of the plots surveyed and contains $81 \%$ of all species identified. Thus, even though the residential plots have a relatively low stem density, this land use type has the highest alpha diversity (Tables 3 and 4). Of the 145 species identified, 42\% were represented by only one or two individuals, while the most common species (Thuja occidentalis) is represented by 179 individuals, or $13 \%$ of the residential stem count (Table 3). Thus, the pattern of many rare species and a few dominant species corresponds to the residential plots exhibiting very low evenness. Based on average pair-wise $\beta_{\mathrm{H} 1}$ values, the tree community associated with residential plots is relatively unique, but is most similar to vacant land $\left(\beta_{\mathrm{H} 1}=\right.$ 38.76).

Vacant land represents $16 \%$ of the plots surveyed and contains $49 \%$ of all species identified. Stem density is highest on vacant land, while the average number of species per plot 
is in line with most other land use types (Table 3). Of the 88 species identified, $40 \%$ were represented by only one or two individuals, which is very similar to the proportion of rare species on residential land. The three most common species are all represented by over 225 individuals each, comprising $51 \%$ of the stems in the vacant plots (Table 3); vacant land has the lowest evenness of any of the land use types.

Commercial land diverges from the pattern seen across residential and vacant plots; it has a very low average number of stems and species per plot, but a relatively high alpha diversity when considering all commercial plots together. This is because there are 43 species represented by only 126 stems on the 37 commercial plots. Commercial land also has the highest evenness values in this study. While $63 \%$ of the species are represented in commercial plots by only one or two individuals, the most common species has only 12 individuals. Another characteristic unique to commercial land use plots is the dominance of non-native species. Of the 10 most abundant species on each land use type, between seven and nine are native (Table 5). The exception to this is commercial plots, where only four of the 10 most abundant species are native.

The fourth most frequent land use type sampled, parkland, has moderate values for average numbers of stems and species per plot, as compared to the other land use types. Alpha diversity values also fall in the middle of the range seen in this study. The evenness value, however, is relatively low. These diversity values are primarily a result of two factors. First, $56 \%$ of the species located in park plots are represented by only one or two individuals, the second highest proportion of rare species among the eight land use types. Second, the most common species represents $34 \%$ of all stems in park plots (Table 5). 
Post-Print Version of Bourne and Conway, 2014; DOI 10.1007/s11252-013-0317-0

In additionally to being taxonomically uneven, the spatial distribution of common species is highly clustered on parkland. For example, the vast majority (89\%) of the most abundant species in parkland, Rhus typhina, is limited to a single locality within Peel. Because of this, $R$. typhina cannot be considered a recurrent component of the landscape, even in parkland, despite it being the fifth most abundant species in the sample. Whether or not to consider $R$. typhina a tree or a shrub has been debated (Meaghan Eastwood, TRCA, personal communication). It was decided for this study that it should be considered a tree because it commonly grows to a height of six metres (Farrar 1995) and it is classified as a tree in many reference guides (Farrar 1995; Hosie 1979). However, when considering the density of the species compared to others, it should be taken into account that in reaching maturity, stems may be substantially smaller than their maximum thickness of $10 \mathrm{~cm}$ (Farrar 1995).

Even if Rhus typhina is excluded, parkland is still dominated by a few species. With $R$. typhina, the three most common species represent $55 \%$ of all stems. When excluded, that number is $40 \%$, and the most common species accounts for $19 \%$ of all park stems.

Municipalities

The four municipalities also vary by average plot-level stem count, observed species richness, and the number of plots (Table 6). Caledon has an average per plot stem density between two and four times higher than the other municipalities, but has the lowest number of observed species. The two biggest municipalities (Brampton and Mississauga) have the lowest average stem density and number of species per plot. 
Post-Print Version of Bourne and Conway, 2014; DOI 10.1007/s11252-013-0317-0

Species accumulation curves indicate that for each municipality sampling was much closer to being exhaustive than it was for many of the land use classes (Figure 4). Bolton and Caledon produced curving graphs, most similar to the parkland and commercial curves.

Brampton and Mississauga produce species accumulate curves that come closest to reaching an asymptote. Therefore, diversity measures taken from these municipalities relatively accurately represent the composition of tree species within them. ANOVA results indicated that significant differences exist in plot-level stem abundance $(\mathrm{F}=-5.14, \mathrm{p}<0.05)$ and species richness $(\mathrm{F}=$ 1.49, $\mathrm{p}<0.05$ ) by municipality, though these relationships are less strong than for land use.

The municipal values for the Shannon-Weiner index were higher on average than they were for the individual land use types (Table 7). Again, the results for $C$ corroborate the rankings produced by H’, with municipalities ranked from highest to least diverse as: Mississauga, Bolton, Brampton, Caledon. Across all four municipalities evenness is very low. Mississauga has the highest alpha diversity and evenness values, with the most common species, Rhus typhina, accounting for only $14 \%$ of all stems in the sample. Caledon has the lowest alpha diversity and evenness values, and the two most common species, Thuja occidentalis and Faxinus Americana, representing 37\% and 17\% respectively. The most common species, when broken down by municipality, are primarily native (Table 8).

Overall, the municipalities are more similar to each other in species composition than when comparing land use types (Table 7). The municipality pairing with the greatest betweenplot species diversity is Mississauga and Caledon ( $\left.\beta_{\mathrm{H} 1} 51.11\right)$. The two municipalities with the most shared species are Caledon and Bolton; only 38 percent of their populations are mutually exclusive. 


\section{Discussion}

Based on the sampled plots in Peel Region, the urban forest is comprised of a few common and many rare tree species. While this pattern holds for all land use types examined, there are differences in the forest composition between the eight land uses. Specifically, stem density, alpha diversity, evenness, and species composition varies, with many species found on only one land use type within the sampled plots. While more exhaustive sampling would likely increase alpha diversity metrics, it would probably not increase evenness as rare species are often overlooked when under-sampling occurs.

The documented differences in diversity-levels and species composition between urban land use types indicates that future work needs to explicitly acknowledge land use composition when documenting urban tree species patterns and exploring mechanisms associated with those patterns; aggregation of urban land use types likely obscures key factors associated with citywide variations. Studies using an urbanization gradient approach should consider ways of incorporating land use composition, using a composite index at a minimum. Research examining differences associated with neighborhood-level conditions need to account for land use within each neighborhood to better understand urban forest patterns and explore if socioeconomic correlations are partially a result of differences in land use composition.

Of the land use types considered in more detail, residential plots had the largest alpha indices highlighting the high level of tree diversity typically found on this land use type (Stewart et al. 2009). The high species diversity is likely due to the variety of social factors influencing residential property management (Troy et al. 2007), which do not affect other land use types to such a degree. Homeowners' emphasis on aesthetics contributed to a high number of exotic 
species, while possessing unique and rare species is often used as a way of showcasing wealth or specific cultural values (Marco et al. 2010). Thus, the typical residential parcel has only one or two individuals of any given species. Many other studies have examined (vascular) plant species composition on residential land and also found high levels of species richness, a high percentage of exotics, and that species composition is strongly shaped by the behavior of their owners (Smith et al. 2006). Thus, the high tree species diversity documented in this study is not surprising given the cultural diversity of Peel Region. Relatively few exotic trees were identified in this study as compared to studies focused on vascular plants, but the results are in line with tree species composition in other North American cities (Nowak 2010).

Alternatively, the high richness found across residential land use plots may be partially a result of the breadth of the residential land use class. The wide diversity of building types (single family through to apartment towers) and properties size means that available planting space and site conditions are highly varied within this single land use class. Future work should more carefully examine the variation in residential conditions, in addition to the socioeconomic characteristics that have been the more recent focus of residential tree studies, to further explore species diversity patterns.

While there are many species present, residential land has very low evenness, a finding that is also supported by the literature (Sudha and Ravindranath 2000). High unevenness likely results from the mix of unique species often favored by residents and the few species frequently used along property edges. The most common species present in these residential plots are those used to create visual barriers (i.e. Thuja occidentalis) and historically popular street trees (i.e. Acer platanoides), and are not the unique exotics found in much lower numbers. As street tree planting is the responsibility of the municipality, diversifying these trees is likely the simplest 
Post-Print Version of Bourne and Conway, 2014; DOI 10.1007/s11252-013-0317-0

way to in increase evenness in residential areas, given the large number of actors (i.e. property owners) who control relatively small areas within this land use type.

Vacant land in Peel possesses mid-range alpha diversity values, but has the highest ranking for average stem abundance per plot. This is similar to the results of the UFORE data analysis in Chicago (Nowak 2010), who found their 'open space' land use category ranked first for number of trees per area and leaf area index. Such a trend is not surprising on vacant land, as it is not actively being used for any purpose, thus planting areas are not limited by human activities. The most common species is the same as for residential, while the second most common species (Rhamnus cuthartica) is invasive in the region; its presence is likely due to the absence of active management and disturbed conditions found on most vacant land plots. The risk of such invasive species expanding on to surrounding land should be assessed. Efforts to actively manage these lands for high diversity, given a lack of constraints by land use activities, should be adopted. This could be achieved with the help of resident associations and other community groups who would benefit from such management.

Commercial land as a specific land use designation is not often considered in the urban forestry literature. One study that does investigate commercial land found that in Bangalore City (India) it has a relatively low Shannon-Weiner index (1.549) and very low tree density (Sudha and Ravindranath 2000). Ningal et al. (2010) had similar findings for commercial land in central Dublin, Ireland. While Peel's commercial areas have a much higher alpha diversity value, a very low stem density was consistent with the results from Bangalore and Dublin.

In Peel, many of the commercial lands are highly managed by professional landscaping companies, who likely choose from a relatively narrow range of species that can withstand 
conditions produced by adjacent streets, parking lots and sidewalks. This management likely is the prime contributor to the high evenness, and the high number of exotic species is further evidence of active planting decisions. Even with the low stem density, prior research has shown that business improvement associations are interested in planting trees to create aesthetically pleasing environments that will attract customers (Conway et al. 2011). Yet, commercial areas often have very large areas of impervious surface (typically in the form of parking lots) which limit planting opportunities (Pauleit 2003). These factors suggest steps should be taken to increase available tree planting area, including reviewing zoning requirements regarding parking lot design, and may be positively received by many business owners. Efforts could also be made to diversity plantings, but it is difficult to find a wide range of species that can survive the highlevels of car activity typical of commercial land.

The alpha and evenness values for Peel's parkland is lower than would be expected given the well documented trend for the natural heterogeneity of activities within parks to yield relatively high diversity values (Jim and Chen 2009; Jim and Liu 2001). For example, across ten Nordic cities Sjöman et al. (2011) found a greater diversity of trees in parks than along streets running through a variety of urban land uses. If Rhus typhina were removed from this analysis, the evenness measure would slightly increase due to its dominance on parkland, but average stem density would decrease by nearly half. A possible explanation is that the parks included in the analysis are primarily small, neighborhoods parks with playing fields and other recreational facilities. Thus, the number and diversity of trees may be lower than in parkland that is less intensely managed and/or comprised of larger tracts. Cornelis and Hermy (2004) found that large woodlots in Flanders had higher species richness than the combined richness of several smaller woodlots totaling the same area, supporting this explanation. 
Comparing the municipalities, there is less variation in the diversity metrics and tree composition than for land use. This is parallel to results from three towns in South Africa, where differences in diversity within each town were greater than differences between the towns (Kurueri-Chitepo and Shakleton 2011). The diversity that exists between municipalities in this study is likely a result of the heterogeneity of land use types within each municipality. However, more extensive sampling of each land use type is needed to fully examine this issue.

The higher alpha-values for the municipalities, as compared to the land use types, are not surprising as each municipality is composed of many different land use types that have their own set of associated species. All but Caledon are at the high end of typical Simpson-Weiner values (1.7 to 3.1) and total number of species identified in samples collected following a similar UFORE protocol ${ }^{1}$ in North American urban municipalities (Nowak 2010). With regard to the differences that do exist, contextual and historical factors may explain some of the variation. Mississauga and Brampton have the highest density of people and greatest intensity of urban land uses, which may account for the relatively low stem density. Mississauga directly borders the City of Toronto and has several major highways crossing the municipality; both contributed to (sub)urban-style development beginning earlier here than in the other municipalities. The relatively extended history of such development has allowed for a longer period of planting on urban sites across the municipality, which may account for the higher diversity levels. Age of housing development is well documented in its relation to tree canopy size (Troy et al. 2007), but it may also be associated with the level of species diversity. However, more research on this and other potential correlates of urban forest species diversity, beyond land use type, is needed.

\footnotetext{
${ }^{1}$ While plot size is constant, there is variation in the number of plots and method used to locate plots within cities.
} 
Conversely, the sample from Caledon has the lowest alpha diversity values, but the highest average number of stems per plot. Caledon has not experienced the high population growth or influx of diverse immigrant groups that has shaped Mississauga over many decades, and Brampton more recently. Its smaller size, slower rates of land use change and less intensive urban land uses, may have facilitated its relatively high stem density and low alpha-diversity levels. Additionally, Mississauga’s high alpha-value may be a result of it containing the largest number of plots, while Caledon is geographically small and contains fewer plots; previous studies have found a positive relationship between land area and species richness (Angold et al. 2006).

Several authors have identified an urban forest species diversity management target of: no species should account for more than $10 \%$ of the entire tree population (Grey and Deneke 1986; Miller and Miller 1991). Kenney et al. (2011) further defined a gradient of performance levels for species diversity to help managers assess the health of the urban forest. Based on the sampled population in this study, Peel exceeds both Kenney et al's 'low' level, where fewer than five species dominate the majority of the tree population, and 'moderate' level, where no tree species exceeds $20 \%$ of the sampled population. However, two species do not meet the 'good' performance level, representing more than $10 \%$ of the total tree population. The results are not as strong at the municipal-level: Brampton and Caledon both have one species representing more than $20 \%$ of the total sample, Bolton has two species representing more than $10 \%$ each, and Mississauga has one.

While only eight percent of stems in the sample, the significant presence of Fraxinus americana on all but commercial land use, and its dominance in Caledon, indicate a major vulnerability in Peel's urban forest given the presence of Emerald Ash Borer within the region 
Post-Print Version of Bourne and Conway, 2014; DOI 10.1007/s11252-013-0317-0

(Region of Peel 2011). It also highlights the vulnerability of uneven species representation, and has contributed to Peel's focus on increasing species richness and evenness levels in its urban forest (TRCA 2011).

There are a few limitations with the dataset used in this study. First, land use types were not proportionally represented across municipalities, so the dominance of specific species within each municipality may be misleading since land use type is strongly related to the species present; more representative land use sampling in the municipalities may find individual species are less dominant than this analysis indicates. Second, several less common land uses were under-sampled, raising questions about the accuracy of the diversity metrics for these land uses. Finally, the sampling protocol counted stems not trees. As a result, trees that typical have multiple stems are likely to be overrepresented. Alternatively, use of stem counts in this study mirrors other samples collected for UFORE analysis, allowing these results to be comparable to other cities. Given these caveats, the results clearly indicate differences in tree species composition and diversity between land use types, suggesting that future research needs to account for the effects of land use composition and explore the role of land use-related factors in causal processes.

\section{Conclusions}

This study found variations between urban land use types in tree species composition and diversity metrics, with a large number of species limited to only one land use type. The extent of these differences is greater between land uses than neighboring municipalities. These results emphasize the importance of differentiating between urban land uses when examining urban 
Post-Print Version of Bourne and Conway, 2014; DOI 10.1007/s11252-013-0317-0

forest patterns and casual processes. Given the land use-based heterogeneity, strategies tailored to each land use type should be adopted to maintain a healthy and diverse urban forest. Some differences were also identified between the four municipalities, which are likely related to their development histories and current land use composition. Future work should more thoroughly sample less common land uses and explore tree planting and removal processes associated with each land use type to fully understand the variations in causal processes. 
Post-Print Version of Bourne and Conway, 2014; DOI 10.1007/s11252-013-0317-0

\section{Acknowledgments}

The authors would like to thank Lionel Nelson and Meaghan Eastwood at the Toronto and

Region Conservation Authority for providing the tree data. This research was supported by a grant from the Canadian Social Science and Humanities Research Council. 
Post-Print Version of Bourne and Conway, 2014; DOI 10.1007/s11252-013-0317-0

\section{References}

Acar C, Acar H, Eroglu E (2007) Evaluation of ornamental plant resources to urban biodiversity and cultural changing: a case study of residential landscapes in Trabzon city (Turkey). Building and Environ 42(1): 218-229.

Allison L, Thompson K, Warren PH, Gaston KJ (2008) Urban domestic gardens (XII): The richness and composition of the flora in five UK cities. J Veg Sci 19:321-330

Alvey AA (2006) Promoting and preserving biodiversity in the urban forest. Urban Forest and Urban Green 5:195-201

Angold PG, Sadler JP, Hill MO, Pullin A, Rushton S, Austin K, Small E, Wood B, Wadsworth R, Sanderson R, Thompson K (2006) Biodiversity in urban habitat patches. Sci Total Environ 360:196-204.

Berland A (2012) Long-term urbanization effects on tree canopy cover along an urban-rural gradient. Urban Ecosyst 15(3): 721-738.

Burton ML, Samuelson LJ, Pan S (2005) Riparian woody plant diversity and forest structure along an urban-rural gradient. Urban Ecosyst 8(1): 93-106

Cilliers S (2010) Social aspects of urban biodiversity- An overview. In: Müller N, Werner P, Kelcey JG Urban biodiversity and design. Wiley-Blackwell, Hoboken, NJ, pp. 81-100

Cohen M , Baudoin R, Palibrk M, Persyn N, Rhein C (2012) Urban biodiversity and social inequalities in built-up cities: New evidences, next questions. The example of Paris, France. Land and Urban Plann 106(3): 277-287.

Conway, TM, Hackworth, J (2007) Urban pattern and land cover variation in the Greater Toronto Area. Canadian Geog 51(1):43-57

Conway, TM, Shakeel T, Attallha J (2011) Community groups and urban forestry activity: Drivers of uneven canopy cover? Land and Urban Plann 101(4):321-329 
Post-Print Version of Bourne and Conway, 2014; DOI 10.1007/s11252-013-0317-0

Cornelis J, Hermy M (2004) Biodiversity relationships in urban and suburban parks in Flanders. Land and Urban Plann 69(4):385-401

Dallimer M, Rouquette JR, Skinner AMJ, Armsworth PR, Maltby LM., Warren PH, Gaston KJ (2012) Contrasting patterns in species richness of birds, butterflies and plants along riparian corridors in an urban landscape. Div and Distrib 18(8): 742-753

Emmanuel R (1997) Urban vegetation change as an indicator of demographic trends in cities: the case of Detroit. Environ and Plann B 42:415-426.

Farrar JL (1995) Trees of the Northern United States and Canada. Fitzhenry and Whiteside Ltd, Markham, Canada

Flocks J, Escobedo F, Wade J, Varela S, Wald C (2011) Environmental justice implications of urban tree cover in Miami-Dade County, Florida. Environ Justice 4(2): 125-134. doi:10.1089/env.2010.0018.

Goddard MA, Dougill AJ, Benton TG (2010) Scaling up from gardens: Biodiversity conservation in urban environments. Trends in Ecol and Evol 25(2):90-98

Godefroid S, Koedam N (2006) Urban plant species patterns are highly driven by density and function of built-up areas. Land Ecol 22,1127-1239

Grey GW, Deneke FJ (1986) Urban forestry. 2nd ed. John Wiley \& Sons, Toronto.

Grineski S, Bolin B, Boone C (2007) Criteria air pollution and marginalized populations: environmental inequity in metropolitan Phoenix, Arizona. Social Sci Quart 88(2): 535-554. Groombridge B, Jenkins MD (2002) World atlas of biodiversity: earth's living resources in the $21^{\text {st }}$ Century. University of California Press, Berkeley, CA.

Harrison S, Ross SL, Lawton, JH (1992) Beta diversity on geographic gradients in Britain. J Anim Ecol 61 (1):151-158 
Post-Print Version of Bourne and Conway, 2014; DOI 10.1007/s11252-013-0317-0

Heynen N, Perkins HA, Roy P (2006) The political ecology of uneven green space: the impact of political economy on race and ethnicity in producing environmental inequality in Milwaukee. Urban Affairs Review 42(1): 3-25.

Heynen NC, Lindsay G (2003) Correlates of urban forest canopy cover: implications for local public works. Public Works, Manage and Policy 8(1):33-47

Hobbs ER (1988) Species richness of urban forest patches and implications for urban landscape diversity. Land Ecol 1(3)141-152

Hope D, Gies C, Casagrande D, Redman CL, Grimm NB, Martin C (2006) Drivers of spatial variation in plant diversity across the Central Arizona-Phoenix Ecosystem. Soc and Nat Resourc 19(2): 101-116.

Hope D, Gies C, Zhu W, Fagab WF, Redman CL, Grimm NB, Nelson AL, Martin C, Kinzig A (2003) Socioeconomics drive urban plant diversity. Proc Nat Acad Sci 100(15): 87888792.

Hosie RC (1979) Native trees of Canada. Fitzhenry and Whiteside Ltd, Markham, Canada Iverson LR, Cook EA (2000) Urban forest cover of the Chicago region and its relation to household density and income. Urban Ecosyst 4:105-124

Jim CY, Liu HT (2001) Species diversity of three major urban forest types in Guangzhou City, China. Forest Ecol and Manage 146: 99-114.

Jim, CY, Chen WY (2009) Diversity and distribution of landscape trees in the compact Asian city of Taipei. Appl Geogr 29:577-587

Kenney WA, Van Wassenaer PJE, Satel AL (2011) Criteria and indicators for strategic urban forest planning and management. Arboric and Urban Forest 37(3):108-117 
Post-Print Version of Bourne and Conway, 2014; DOI 10.1007/s11252-013-0317-0

Kuruneri-Chitepo C, Shackleton CM (2011) The distribution, abundance and composition of street trees in selected towns of the Eastern Cape, South Africa. Urban Forest and Urban Green 10(3):247-254

Landry SM, Charkraborty J (2009) Street trees and equity: Evaluating the spatial distribution of an urban amenity. Environ and Plann A 41:2651-2670

Lubbe CS, Siebert SJ, Cilliers SS (2010) Political legacy of South Africa affects the plant diversity patterns of urban domestic gardens along a socio-economic gradient. Scientific Research and Essays 5(19): 2900-2910.

Magurran AE (1988) Ecological diversity and its measurement. Princeton University Press, New Jersey

Magurran AE (2004) Measuring biological diversity. Blackwell Publishing, Malden, USA

Marco A, Barthelemy C, Dutoit T, Bertaudière-Montes V (2010) Bridging human and natural sciences for a better understanding of urban floral patterns: The role of planting practices in Mediterranean gardens. Ecol and Soc 15(2): 2.

McDonnell MJ, Hahs AK (2008) The use of gradient analysis studies in advancing our understanding of the ecology of urbanizing landscapes: current status and future directions. Land Ecol 23: 1143-1155.

McDonnell MJ, Pickett STA (1990) Ecosystem structure and function along urban-rural gradients: an unexploited opportunity for ecology. Ecol 71:1232-1237.

Millard A (2010) Cultural aspects of urban biodiversity. In: Müller N, Werner P, Kelcey JG Urban biodiversity and design. Wiley-Blackwell, Hoboken, NJ, pp.56-80

Miller RH and Miller RW (1991) Planting survival of selected street tree taxa. J Arboric 17: 185191. 
Post-Print Version of Bourne and Conway, 2014; DOI 10.1007/s11252-013-0317-0

Muthulingam U, Thangavel S (2012) Density, diversity and richness of woody plants in urban green spaces: A case study in Chennai metropolitan city. Urban Forest and Urban Green 11(4): 450-459.

Nagendra H, Gopal D (2010) Street trees in Bangalore: Density, diversity, composition and distribution. Urban Forest and Urban Green 9(2):129-137

Ningal T, Mills G, Smithwick P (2010) An inventory of trees in Dublin city centre. Irish Geogr 43(20:161-176

Nowak DJ (2010) Urban Biodiversity and Climate Change. In: Müller N, Werner P, Kelcey JG Urban biodiversity and design. Wiley-Blackwell, Hoboken, NJ, pp 101-117

Ortega-Álvarez R, Rodríguez-Correa HA, MacGregor-Fors I (2011) Trees and the city: Diversity and composition along a neotropical gradient of urbanization. Int J Ecol, art. no. 704084.

Pauleit S (2003) Urban street tree plantings: identifying the key requirements. Proceed Instit of Civil Engineers: Municipal Engineer 156(1):43-50

Pedlowski MA, Adell JJC, Heynen NC (2002) Urban forest and environmental inequality in Campos dos Goytacazes, Rio de Janeiro, Brazil. Urban Ecosystems 6: 9-20.

Pham TTH, Apparicio P, Séguin AM, Landry S, Gagnon M (2012) Spatial distribution of vegetation in Montreal: An uneven distribution or environmental inequity? Land and Urban Plann 107(3): 214-224.

Porter EE, Forschner BR, Blair RB (2001) Woody vegetation and canopy fragmentation along a forest-to-urban gradient. Urban Ecosyst 5(2): 131-151

Ramalho CE, Hobbs RJ (2012) Time for a change: Dynamic urban ecology. Trends in Ecol and Evol 27(3): 179-188 
Post-Print Version of Bourne and Conway, 2014; DOI 10.1007/s11252-013-0317-0

Region of Peel (2011) Emerald Ash Borer. Public Works, Region of Peel. http://www.peelregion.ca/pw/waste/eab-old.htm. Accessed 9 February 2012

Seaby RM, Henderson PA (2006) Species diversity and richness. Version 4. Pisces Conservation Ltd, Lymington, England

Sjöman H, Östberg J, Bühler O (2011) Diversity and distribution of the urban tree population in ten major Nordic cities. Urban Forest and Urban Green (1): 31-39

Smith RM, Gaston KJ, Warren PH, Thompson K (2005) Urban domestic gardens (V): Relationships between landcover composition, housing and landscape. Land Ecol 20(2):235-253

Southwood TRE, Henderson PA (2000) Ecological methods. Blackwell Science, Oxford

Stewart GH, Meurk CD, Ignatieva ME, Buckley HL, Magueur A, Case BS, Hudson M, Parker M (2009) Urban Biotopes of Aotearoa New Zealand (URBANZ) II: Floristics, biodiversity and conservation values of urban residential and public woodlands, Christchurch. Urban Forest and Urban Green 8(3):149-162.

Sudha P, Ravindranath NH (2000) A study of Bangalore urban forest. Land and Urban Plann 47:47-63

Talarchek GM (1990) The urban forest of New Orleans- an exploratory analysis of relationships. Urban Geogr 11: 65-86

Tanner RA Gange AC (2005) Effects of golf courses on local biodiversity. Land and Urban Plann 71:137-146

Thompson K, Austin KC, Smith RM, Warren PH, Angold PG, Gaston KJ (2003) Urban domestic gardens (I): Putting small-scale plant diversity in context. J of Veg Sci 14(1):7178 
Post-Print Version of Bourne and Conway, 2014; DOI 10.1007/s11252-013-0317-0

Trammell TLE, Carreiro MM (2011) Vegetation composition and structure of woody plant communities along urban interstate corridors in Louisville, KY, U.S.A. Urban Ecosyst $14(4): 501-524$

TRCA (2011) Peel urban forest strategy. Toronto and Region Conservation Authority, Toronto, ON.

Troy AR, Grove JM, O’Neil-Dunne JPM, Pickett STA, Cadenasso ML (2007) Predicting opportunities for greening and patterns of vegetation on private urban lands. Environ Manag 40:394-412

Tyrväinen L, Pauleit S, Seeland K, De Vries S (2005) Benefits and uses of urban forest and trees. In: Konijnendijk CC, Nilsson K, Randrup TB, Schipperijn J (eds) Urban forests and trees: A reference book. Springer, New York, pp 81-115

USDA 2011. i-Tree Eco. USDA Forest Service. http://www.itreetools.org/eco/index.php. Accessed 23 February 2012.

Waite S (2000) Statistical ecology in practice. Pearson Education Ltd, Essex Waldron G (2002) Trees of the Carolinian forest: guide to species, their ecology and uses. Boston Mills Press, Erin, Ontario

Weifeng L, Zhiyum O, Zuesong M, Ziaoke W (2006) plant species composition in relation to green cover configuration and function of urban parks in Beijing, China. Ecol Res 21:221237.

Whittaker RH (1960) Vegetation of the Siskiyou Mountains, Oregon and California. Ecol Monograph 30: 279-338

Zipperer WC, Rowntree RA, Stevens JC (1991) Structure and composition of streetside trees of residential areas in State of Maryland, USA. Arboric J 15(1):1-11 
Post-Print Version of Bourne and Conway, 2014; DOI 10.1007/s11252-013-0317-0

Zipperer WC, Zipperer CE (1992) Vegetation responses to changes in design and management of an urban park. Land and Urban Plann 22(1):1-10 
Post-Print Version of Bourne and Conway, 2014; DOI 10.1007/s11252-013-0317-0

Table 1. Characteristics of the four urban municipalities, in 2006.

\begin{tabular}{lrrrr}
\hline Municipality & Population & \multicolumn{1}{c}{$\begin{array}{c}\text { Population } \\
\text { Density } \\
\text { (per sq. Km) }\end{array}$} & Median Income & $\begin{array}{c}\text { Percent } \\
\text { Immigrants }\end{array}$ \\
\hline Bolton & 24,492 & 2,197 & 34,784 & 20 \\
Brampton & 433,806 & 1,626 & 26,345 & 48 \\
Caledon & 2,214 & 826 & 35,676 & 21 \\
Mississauga & 668,549 & 2,317 & 27,788 & 52 \\
\hline
\end{tabular}


Post-Print Version of Bourne and Conway, 2014; DOI 10.1007/s11252-013-0317-0

Table 2. Description of land use classes examined.

\begin{tabular}{|c|c|}
\hline Land Use Class & Description \\
\hline Agriculture & $\begin{array}{l}\text { Farms, including greenhouse operations, orchards, wineries, and houses on } \\
\text { properties primary used for farming }\end{array}$ \\
\hline Commercial & Office buildings; service and retail establishments \\
\hline Golf & Private and municipal golf courses \\
\hline Institutional & $\begin{array}{l}\text { Government uses, including firehouses and ambulance stations; Educational } \\
\text { campuses; Hospitals and long-term care facilities; Places of worship }\end{array}$ \\
\hline Parkland & Municipal parks \\
\hline Residential & $\begin{array}{l}\text { Single family homes; Semi-detached homes; Townhouses; Apartment } \\
\text { buildings }\end{array}$ \\
\hline Transportation & Roads; Railways; Airports; Utilities rights-of-way \\
\hline Vacant & No current use \\
\hline
\end{tabular}


Post-Print Version of Bourne and Conway, 2014; DOI 10.1007/s11252-013-0317-0

Table 3. Stem counts and species richness by land use type.

\begin{tabular}{lccccc}
\hline Land Use Type & $\begin{array}{c}\text { Raw Stem } \\
\text { Count }\end{array}$ & $\begin{array}{c}\text { Raw } \\
\text { Species } \\
\text { Count }\end{array}$ & $\begin{array}{c}\text { Number of } \\
\text { Plots }\end{array}$ & $\begin{array}{c}\text { Average } \\
\text { Number of } \\
\text { Stem per Plot }\end{array}$ & $\begin{array}{c}\text { Average } \\
\text { Number of } \\
\text { Species per } \\
\text { Plot }\end{array}$ \\
\hline Agriculture & 22 & 10 & 7 & 3 & 2 \\
Commercial & 126 & 43 & 37 & 3 & 2 \\
Golf & 116 & 15 & 3 & 39 & 6 \\
Institutional & 96 & 26 & 8 & 12 & 5 \\
Parkland & 450 & 48 & 22 & 21 & 5 \\
Residential & 1312 & 145 & 146 & 9 & 5 \\
Transportation & 212 & 29 & 10 & 21 & 6 \\
Vacant & 1788 & 88 & 46 & 39 & 5 \\
Peel & 4122 & 179 & 279 & 15 & 5 \\
\hline
\end{tabular}


Post-Print Version of Bourne and Conway, 2014; DOI 10.1007/s11252-013-0317-0

Table 4. Alpha, evenness and beta diversity by land use type. H' = Shannon-Weiner Index; $\mathrm{C}=$ Simpson’s Index; E = Simpson's Evenness Measure; $\mathrm{B}_{\mathrm{H} 1}=$ Harrison's Beta Diversity

\begin{tabular}{lcccc}
\hline Land Use Type & H' & C & E & $\begin{array}{c}\text { Mean Pair-wise } \\
\beta_{\mathrm{H} 1} \text { Value }\end{array}$ \\
\hline Agriculture & 1.855 & 4.813 & 0.4812 & 69.28 \\
Commercial & 3.388 & 26.88 & 0.625 & 59.29 \\
Golf & 1.796 & 3.88 & 0.2587 & 68.82 \\
Institutional & 2.686 & 10.36 & 0.3986 & 59.35 \\
Park & 2.606 & 6.355 & 0.1324 & 52.43 \\
Residential & 4.082 & 28.85 & 0.1989 & 66.47 \\
Transportation & 2.239 & 5.256 & 0.1813 & 57.24 \\
Vacant & 2.948 & 9.528 & 0.1083 & 55.25 \\
\hline
\end{tabular}


Table 5. The ten most abundant species by land use type. The number in parenthesis is the percent of stems on the specific land use represented by that species. Native, naturalized, and introduced status based on Farrar (1995) and Hosie (1979).

\begin{tabular}{|c|c|c|c|c|c|c|c|}
\hline Agriculture & Commercial & Golf & Institutional & Parkland & Residential & Transportation & Vacant \\
\hline $\begin{array}{c}\text { Rhammus } \\
\text { cathartica } \\
(45 \%) \\
\text { naturalized }\end{array}$ & $\begin{array}{c}\text { Picea pungens } \\
(10 \%) \\
\text { introduced }\end{array}$ & $\begin{array}{c}\text { Rhammus } \\
\text { cathartica } \\
(44 \%) \\
\text { naturalized }\end{array}$ & $\begin{array}{c}\text { Pinus resinosa } \\
(22 \%) \\
\text { native }\end{array}$ & $\begin{array}{c}\text { Rhus typhina } \\
\text { (35\%) } \\
\text { native }\end{array}$ & $\begin{array}{c}\text { Thuja } \\
\text { occidentalis } \\
\text { (14\%) } \\
\text { native }\end{array}$ & $\begin{array}{c}\text { Populus } \\
\text { tremuloides } \\
\text { (37\%) } \\
\text { native }\end{array}$ & $\begin{array}{c}\text { Thuja } \\
\text { occidentalis } \\
\text { (22\%) } \\
\text { native }\end{array}$ \\
\hline $\begin{array}{c}\text { Acer negundo } \\
\text { (9\%) } \\
\text { native }\end{array}$ & $\begin{array}{c}\text { Picea glauca } \\
(8 \%) \text { native }\end{array}$ & $\begin{array}{c}\text { Pinus resinosa } \\
\text { (24\%) } \\
\text { native }\end{array}$ & $\begin{array}{c}\text { Fraxinus } \\
\text { Americana } \\
\text { (17\%) } \\
\text { native }\end{array}$ & $\begin{array}{c}\text { Acer } \\
\text { saccharum } \\
(13 \%) \\
\text { native }\end{array}$ & $\begin{array}{c}\text { Acer } \\
\text { platanoides } \\
(5 \%) \\
\text { naturalized }\end{array}$ & $\begin{array}{c}\text { Thuja } \\
\text { occidentalis } \\
\text { (20\%) } \\
\text { native }\end{array}$ & $\begin{array}{c}\text { Rhammus } \\
\text { cathartica } \\
(17 \%) \\
\text { naturalized }\end{array}$ \\
\hline $\begin{array}{l}\text { Prunus } \\
\text { (9\%) } \\
\text { native }\end{array}$ & $\begin{array}{c}\text { Acer } \\
\text { platanoides } \\
(6 \%) \\
\text { naturalized }\end{array}$ & $\begin{array}{c}\text { Fraxinus } \\
\text { americana } \\
\quad(6 \%) \\
\text { native }\end{array}$ & $\begin{array}{c}\text { Acer } \\
\text { saccharum } \\
\text { (11\%) } \\
\text { native }\end{array}$ & $\begin{array}{c}\text { Acer negundo } \\
(7 \%) \\
\text { native }\end{array}$ & $\begin{array}{c}\text { Picea glauca } \\
\text { (5\%) } \\
\text { native }\end{array}$ & $\begin{array}{c}\text { Populus } \\
\text { balsumiferu } \\
\text { (10\%) } \\
\text { native }\end{array}$ & $\begin{array}{c}\text { Fraxinus } \\
\text { americana } \\
(13 \%) \\
\text { native }\end{array}$ \\
\hline $\begin{array}{c}\text { Prunus } \\
\text { virginiana } \\
\text { (9\%) } \\
\text { native }\end{array}$ & $\begin{array}{c}\text { Gleditsia } \\
\text { triacanthos } \\
(6 \%) \\
\text { native }\end{array}$ & $\begin{array}{c}\text { Carya } \\
\text { cordiformis } \\
(6 \%) \\
\text { native }\end{array}$ & $\begin{array}{c}\text { Fagus } \\
\text { Americana } \\
\text { (8\%) } \\
\text { native }\end{array}$ & $\begin{array}{c}\text { Pinus } \\
\text { sylvestris } \\
(7 \%) \\
\text { naturalized }\end{array}$ & $\begin{array}{c}\text { Juniperus } \\
\text { (4\%) } \\
\text { native }\end{array}$ & $\begin{array}{c}\text { Rhammus } \\
\text { cathartica } \\
\quad(6 \%) \\
\text { naturalized }\end{array}$ & $\begin{array}{c}\text { Crutargus } \\
\text { (7\%) } \\
\text { native }\end{array}$ \\
\hline $\begin{array}{c}\text { Acer } \\
\text { platanoides } \\
(5 \%) \\
\text { naturalized }\end{array}$ & $\begin{array}{l}\text { Pinus nigra } \\
\quad(6 \%) \\
\text { introduced }\end{array}$ & $\begin{array}{c}\text { Crataegus } \\
(6 \%) \\
\text { native }\end{array}$ & $\begin{array}{c}\text { Rhammus } \\
\text { cathartica } \\
\text { (5\%) } \\
\text { naturalized }\end{array}$ & $\begin{array}{c}\text { Fraxinus } \\
\text { americana } \\
(6 \%) \\
\text { native }\end{array}$ & $\begin{array}{c}\text { Fraxinus } \\
\text { americana } \\
(3 \%) \\
\text { native }\end{array}$ & $\begin{array}{c}\text { Fraxinus } \\
\text { Americana } \\
(5 \%) \\
\text { native }\end{array}$ & $\begin{array}{c}\text { Acer } \\
\text { saccharum } \\
(6 \%) \\
\text { native }\end{array}$ \\
\hline $\begin{array}{c}\text { Acer } \\
\text { saccharum } \\
(5 \%) \\
\text { native }\end{array}$ & $\begin{array}{c}\text { Rhammus } \\
\text { cathartica } \\
\quad(6 \%) \\
\text { naturalized }\end{array}$ & $\begin{array}{c}\text { Ostrya } \\
\text { virginiana } \\
\text { (4\%) } \\
\text { native }\end{array}$ & $\begin{array}{c}\text { Acer } \\
\text { platanoides } \\
(3 \%) \\
\text { naturalized }\end{array}$ & $\begin{array}{c}\text { Thuja } \\
\text { occidentalis } \\
(4 \%) \\
\text { native }\end{array}$ & $\begin{array}{c}\text { Rhamnus } \\
\text { cathartica } \\
(3 \%) \\
\text { naturalized }\end{array}$ & $\begin{array}{c}\text { Salix } \\
(3 \%) \\
\text { native }\end{array}$ & $\begin{array}{c}\text { Ostrya } \\
\text { virginiana } \\
(3 \%) \\
\text { native }\end{array}$ \\
\hline $\begin{array}{c}\text { Crutargus } \\
\text { (5\%) } \\
\text { native }\end{array}$ & $\begin{array}{c}\text { Pinus resinosa } \\
\text { (6\%) } \\
\text { native }\end{array}$ & $\begin{array}{c}\text { Acer } \\
\text { saccharum } \\
\text { (3\%) } \\
\text { native }\end{array}$ & $\begin{array}{c}\text { Acer rubrum } \\
\text { (3\%) } \\
\text { native }\end{array}$ & $\begin{array}{c}\text { Rhamnus } \\
\text { cathartica } \\
(3 \%) \\
\text { naturalized }\end{array}$ & $\begin{array}{c}\text { Acer negunda } \\
(3 \%) \\
\text { native }\end{array}$ & $\begin{array}{c}\text { Acer negunda } \\
\text { (2\%) } \\
\text { native }\end{array}$ & $\begin{array}{c}\text { Tilla } \\
\text { Americana } \\
(2 \%) \\
\text { native }\end{array}$ \\
\hline $\begin{array}{l}\text { Gleditsia } \\
\text { triacanthos }\end{array}$ & $\begin{array}{c}\text { Cornus } \\
(4 \%)\end{array}$ & $\begin{array}{c}\text { Acer negunda } \\
(2 \%)\end{array}$ & $\begin{array}{c}\text { Picea glauca } \\
(2 \%)\end{array}$ & $\begin{array}{c}\text { Fraxinus } \\
\text { pennsylvanica }\end{array}$ & $\begin{array}{c}\text { Ulmus } \\
\text { americana }\end{array}$ & $\begin{array}{c}\text { Prunus } \\
\text { virginiana }\end{array}$ & $\begin{array}{l}\text { Fraxinus } \\
\text { nigru }\end{array}$ \\
\hline
\end{tabular}


Post-Print Version of Bourne and Conway, 2014; DOI 10.1007/s11252-013-0317-0

\begin{tabular}{|c|c|c|c|c|c|c|c|}
\hline$(5 \%)$ & native & native & native & $(2 \%)$ & $(2 \%)$ & $(2 \%)$ & $(2 \%)$ \\
\hline native & & & & native & native & native & native \\
\hline $\begin{array}{l}\text { Juniperus } \\
\text { (5\%) native }\end{array}$ & $\begin{array}{c}\text { Lonicera } \\
\quad(3 \%) \\
\text { introduced }\end{array}$ & $\begin{array}{c}\text { Populus } \\
\text { balsamifera } \\
\text { (2\%) } \\
\text { native }\end{array}$ & $\begin{array}{c}\text { Acer negundo } \\
(2 \%) \\
\text { native }\end{array}$ & $\begin{array}{c}\text { Prunus } \\
\text { serotina } \\
(2 \%) \\
\text { native }\end{array}$ & $\begin{array}{c}\text { Fraxinus } \\
\text { pennsylvanica } \\
\text { (2\%) } \\
\text { native }\end{array}$ & $\begin{array}{c}\text { Syringe } \\
\text { vulgans } \\
(2 \%) \\
\text { naturalized }\end{array}$ & $\begin{array}{c}\text { Acer negundo } \\
(2 \%) \\
\text { native }\end{array}$ \\
\hline $\begin{array}{c}\text { Salix } \\
(5 \%) \text { native }\end{array}$ & $\begin{array}{c}\text { Morus alba } \\
\text { (3\%) } \\
\text { naturalized }\end{array}$ & $\begin{array}{c}\text { Malus } \\
\text { domestica } \\
(1 \%) \\
\text { native }\end{array}$ & $\begin{array}{c}\text { Cornus } \\
\text { (2\%) } \\
\text { native }\end{array}$ & $\begin{array}{c}\text { Fagus } \\
\text { Americana } \\
(1 \%) \\
\text { native }\end{array}$ & $\begin{array}{c}\text { Picea pungens } \\
(2 \%) \\
\text { introduced }\end{array}$ & $\begin{array}{c}\text { Crutargus } \\
\text { (1\%) } \\
\text { native }\end{array}$ & $\begin{array}{c}\text { Betula } \\
\text { paryifera } \\
(2 \%) \\
\text { native }\end{array}$ \\
\hline
\end{tabular}


Post-Print Version of Bourne and Conway, 2014; DOI 10.1007/s11252-013-0317-0

Table 6. Stem counts and species richness by municipality.

\begin{tabular}{lccccc}
\hline Municipality & Stem Count & $\begin{array}{c}\text { Species } \\
\text { Count }\end{array}$ & $\begin{array}{c}\text { Number of } \\
\text { Plots }\end{array}$ & $\begin{array}{c}\text { Number of } \\
\text { Stem per } \\
\text { Plot }\end{array}$ & $\begin{array}{c}\text { Number of } \\
\text { Species per } \\
\text { Plot }\end{array}$ \\
\hline Bolton & 480 & 74 & 26 & 19 & 7 \\
Brampton & 1435 & 96 & 109 & 13 & 4 \\
Caledon & 1079 & 65 & 26 & 42 & 7 \\
Mississauga & 1127 & 108 & 118 & 10 & 5 \\
\hline
\end{tabular}


Post-Print Version of Bourne and Conway, 2014; DOI 10.1007/s11252-013-0317-0

Table 7. Alpha, evenness, and beta diversity by municipality. $\mathrm{H}^{\prime}=$ Shannon-Weiner Index; $\mathrm{C}=$ Simpson’s Index; E = Simpson’s Evenness Measure; $\mathrm{B}_{\mathrm{H} 1}=$ Harrison’s Beta Diversity

\begin{tabular}{lcccc}
\hline \multicolumn{1}{c}{ Municipality } & $\mathrm{H}^{\prime}$ & $\mathrm{C}$ & $\mathrm{E}$ & $\begin{array}{c}\text { Mean Pair-wise } \\
\beta_{\mathrm{H} 1} \text { Value }\end{array}$ \\
\hline Bolton & 3.483 & 16.33 & 0.2206 & 43 \\
Brampton & 3.332 & 11.42 & 0.1189 & 48 \\
Caledon & 2.604 & 5.731 & 0.0882 & 45 \\
Mississauga & 3.761 & 23.09 & 0.2138 & 48 \\
\hline
\end{tabular}


Table 8. Ten most abundant species by municipality. The number in parenthesis is the percent of stems in the specific municipality represented by that species. Native, naturalized, and introduced status based on Farrar (1995) and Hosie (1979).

\begin{tabular}{|c|c|c|c|}
\hline Bolton & Brampton & Mississauga & Caledon \\
\hline $\begin{array}{c}\text { Thuja occidentalis } \\
\text { (17\%) } \\
\text { native }\end{array}$ & $\begin{array}{c}\text { Rhamnus cathartica } \\
(26 \%) \\
\text { naturalized }\end{array}$ & $\begin{array}{c}\text { Rhus typhina } \\
\text { (14\%) } \\
\text { native }\end{array}$ & $\begin{array}{c}\text { Thuja occidentalis } \\
\text { (37\%) }\end{array}$ \\
\hline Populus tremuloides & Crataegus & Thuja occidentalis & Fraxinus americana \\
\hline$(14 \%)$ & $(9 \%)$ & $(7 \%)$ & $(17 \%)$ \\
\hline native & native & native & native \\
\hline $\begin{array}{c}\text { Populus balsamifera } \\
\text { (4\%) }\end{array}$ & $\begin{array}{c}\text { Thuja occidentalis } \\
(5 \%)\end{array}$ & $\begin{array}{c}\text { Fraxinus americana } \\
(7 \%)\end{array}$ & $\begin{array}{c}\text { Acer saccharum } \\
(5 \%)\end{array}$ \\
\hline native & native & native & native \\
\hline $\begin{array}{c}\text { Rhamnus cathartica } \\
(4 \%)\end{array}$ & $\begin{array}{c}\text { Fraxinus americana } \\
\qquad(5 \%)\end{array}$ & $\begin{array}{c}\text { Acer saccharum } \\
(7 \%)\end{array}$ & $\begin{array}{c}\text { Pinus sylvestris } \\
(3 \%)\end{array}$ \\
\hline naturalized & native & native & naturalized \\
\hline $\begin{array}{c}\text { Picea glauca } \\
(4 \%)\end{array}$ & $\begin{array}{c}\text { Acer saccharum } \\
(5 \%)\end{array}$ & $\begin{array}{c}\text { Acer negundo } \\
\quad(4 \%)\end{array}$ & $\begin{array}{c}\text { Populus tremuloides } \\
(3 \%)\end{array}$ \\
\hline native & native & native & native \\
\hline $\begin{array}{c}\text { Pinus resinosa } \\
\text { (3\%) }\end{array}$ & $\begin{array}{c}\text { Acer negundo } \\
(4 \%)\end{array}$ & $\begin{array}{c}\text { Acer platanoides } \\
(3 \%)\end{array}$ & $\begin{array}{c}\text { Rhamnus cathartica } \\
\text { (3\%) }\end{array}$ \\
\hline native & native & naturalized & naturalized \\
\hline $\begin{array}{c}\text { Juniperus } \\
\text { (3\%) }\end{array}$ & $\begin{array}{c}\text { Ostrya virginiana } \\
\qquad(3 \%)\end{array}$ & $\begin{array}{c}\text { Fraxinus } \\
\text { pennsylvanica }\end{array}$ & $\begin{array}{c}\text { Betula paryrifera } \\
(3 \%)\end{array}$ \\
\hline native & native & $\begin{array}{l}\text { (3\%) } \\
\text { native }\end{array}$ & native \\
\hline $\begin{array}{l}\text { Fraxinus americana } \\
\qquad(3 \%)\end{array}$ & $\begin{array}{c}\text { Picea glauca } \\
\text { (3\%) }\end{array}$ & $\begin{array}{c}\text { Cornus } \\
(3 \% 0)\end{array}$ & $\begin{array}{c}\text { Pinus resinosa } \\
\text { (2\%) }\end{array}$ \\
\hline native & native & native & native \\
\hline $\begin{array}{c}\text { Prunus virginiana } \\
(2 \%)\end{array}$ & $\begin{array}{c}\text { Acer platanoides } \\
(3 \%)\end{array}$ & $\begin{array}{c}\text { Picea glauca } \\
(2 \%)\end{array}$ & $\begin{array}{c}\text { Ulmus americana } \\
(2 \%)\end{array}$ \\
\hline native & naturalized & native & native \\
\hline $\begin{array}{c}\text { Acer saccharum } \\
(2 \%)\end{array}$ & $\begin{array}{c}\text { Carya cordiformis } \\
(2 \%)\end{array}$ & $\begin{array}{l}\text { Juniperus } \\
\quad(2 \%)\end{array}$ & $\begin{array}{c}\text { Picea abies } \\
\text { (2\%) }\end{array}$ \\
\hline native & native & native & naturalized \\
\hline
\end{tabular}


Post-Print Version of Bourne and Conway, 2014; DOI 10.1007/s11252-013-0317-0

\section{Figures}

Figure 1: Peel region (Ontario, Canada) and its urban municipalities.

Figure 2: Location of plots in Peel.

Figure 3: Species accumulation curves for agriculture (a), golf (b), parkland (c), transportation (d), commercial (e), institutional (f), residential (g), and vacant (h).

Figure 4: Species accumulation curves Bolton (a), Brampton (b), Caledon (c), and Mississauga (d). 


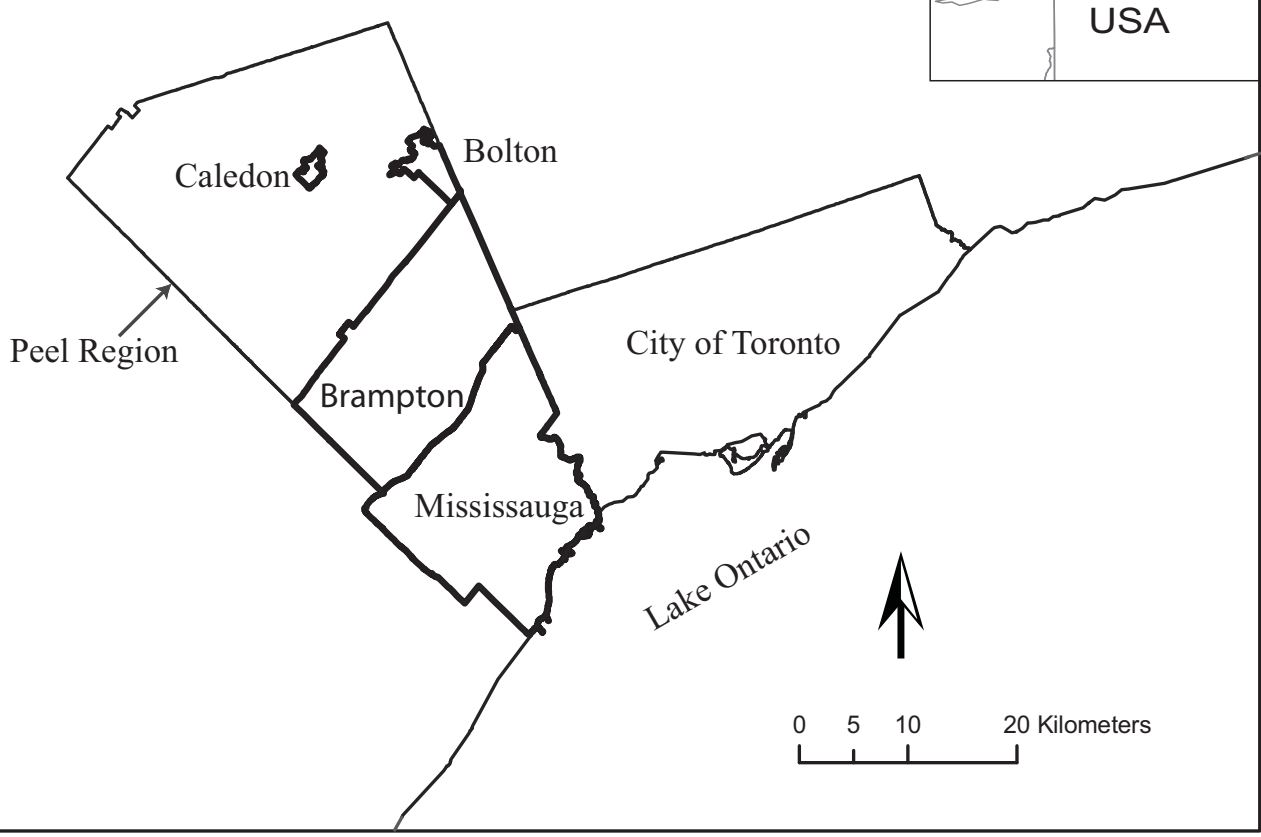




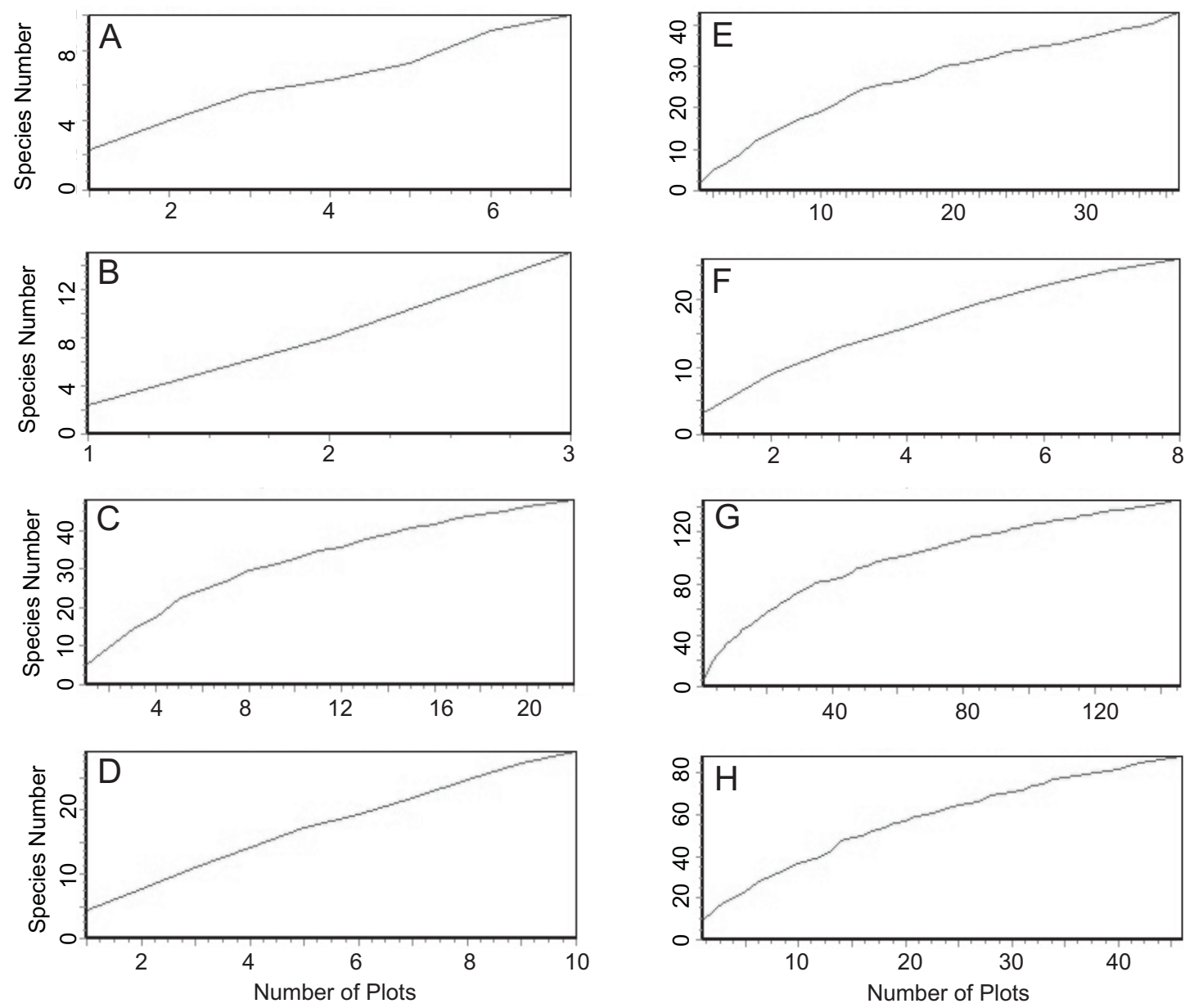

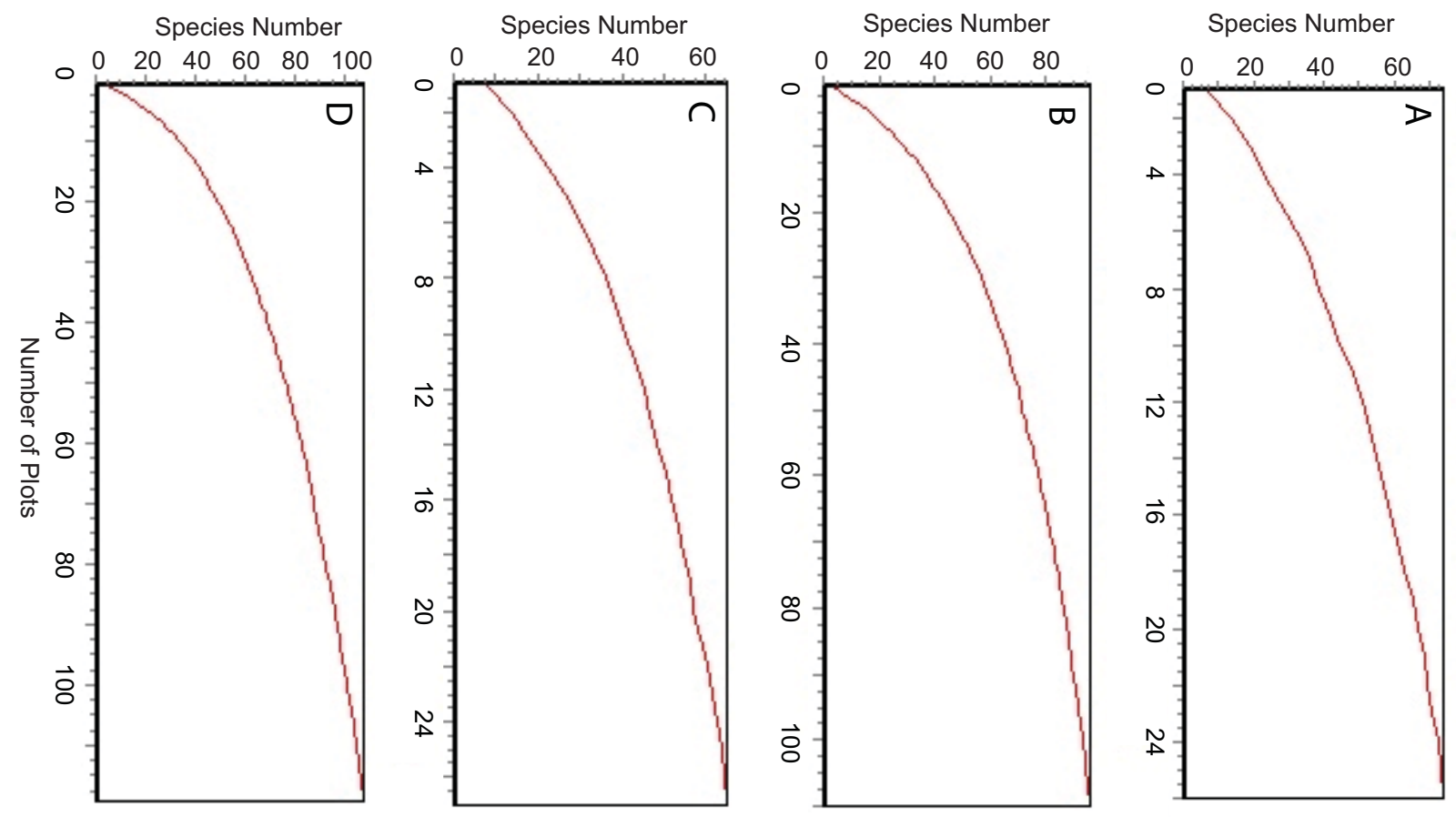